The name Paithan derives from the town's Sanskrit name 'Pratishḥāna', literally translated as 'respectful abode'. The name also has Prakrit variants such as 'Patiṭhāna', 'Patițthāṇa', 'Paëṭhāṇa', etc. Immediately prior to Indian independence in 1947, Paithan was part of the state of the Nizam of Hyderabad. It became part of the Indian Union in 1948, when the Dominion of the Nizam was attached to the union following a police action.

The study of the history of Paithan can be approached mainly from literary and material sources such as inscriptions. These sources help trace it back to the Early Historic period (c. 350 BC).

\section{Literary sources}

Paithan finds extensive mentions in indigenous genre of ancient literature such as Buddhist, Jaina and Brahmanic texts. Amongst non-indigenous sources, its name also features in certain Western texts such as the Periplus of the Erythraen Sea and the Geography of Ptolemy. Myths and folklore have also grown up around the town, and some of these, that incorporate historical strands, are worth a mention.

\section{Buddhist sources}

It is generally believed that Buddhist texts like the jatakas make references to Paithan. Morwanchikar lists the Chulla Kalinga, Baveru and Assaka Jatakas as amongst those which contain such references (Morwanchikar 1985: 10). A reexamination of these sources indicates, however, that the Chulla Kalinga and Assaka Jataka do not mention Paithan. Instead, they mention the country (janapada) of Assaka and the King of Assaka. Morwanchikar has obviously inferred, albeit indirectly, this mention to stand for Paithan.

Assaka (Skt. Aśmaka) is one of the 16 Mahājanapadas mentioned in another Buddhist text, the Anguttara Nikāya (I: 213; IV: 252, 256, 261). It is described as being located along the banks of River Godavari and the only janapada to be situated to the south of the Vindhya Mountains. Its 'capital' was a city named Potali, Potana or Podana. The same is referred to as 'Paudanya' in the Mahabharata (1.122; 1.197). Some early scholars like Bhandarkar identified this name with Paithan (see below), and this seems to be the reason Paithan is often associated with the Assaka janapada. But judging by the fact that Paithan was known by its Prakrit name 'Patițțhāna' and its variations, it is unlikely that Potali or Potana could have been its historical name.

As for the Baveru Jataka mentioned by Morwanchi$k a r$, it is evident that hehas confounded this reference (Morwanchikar 1985: 10, note 24). It is not the Baveru Jataka but the story of Bāvari, the orthodox philosopher, featuring in the Sutta Nipāta, that mentions Paithan (Sutta Nipāta 5th chapter, Pārāyaa Vagga; Sircar 1960: 189). According to this story, Bāvari, having heard of the Buddha and his preaching of a new philosophical doctrine, sent 16 of his chosen disciples to debate it with the Buddha. Bāvari resided in the country ruled by the King of Assaka and his students travelled to the north, to the city of Sāvatthī, to meet the Buddha. The intellectual encounter of Bāvari's students with the Buddha ended in the latter's victory and he managed to convert the students to the very doctrine they had come to debate. The story outlines the route they took to travel northwards by mentioning towns that lay en route, and Patițthanna features as the first town in the list. If Bodhan is regarded as the capital city of Assaka, namely Podana or Potana, this description fits well as Bodhan lies southeast of Paithan and one would indeed travel north to travel from Bodhan to Paithan, thereby also adding further strength to the argument that these are different places.

Paithan is often associated with another janapada named 'Mūlaka' (Morwanchikar 1985: 8; Sircar 1960: 193, 273, note 1). The janapada-names 'Aśmaka' and 'Mūlaka' are often referred to conjointly (possibly due to their occurrence as such in a Satavahana inscription, of a date much later than the Buddha) and it is commonly understood that the mention of Mūlaka, like Aśmaka, is also of aBuddhist origin. It has to be empha- 
sized that Mūlaka does not feature amongst the 16 Mahājanapadas listed in the Anguttara Nikāya (I: 213; IV: $252,256,261)$. Its mention as a janapada is definitively from Brahmanic sources, such as Puranas, which date considerably later than the Buddhist canon. Much like Aśmaka, the country of Mūlaka was also apparently located along the banks of the Godavari and there is nothing to suggest that Paithan was a part of the janapada apart from the fact that it, too, is situated on the Godavari. We find, however, that some mentions of Paithan are reported entirely out of an implied and indirect association with Mūlaka. Yazdani not only suggests that Paithan was located in Mūlaka but he also asserts that it was the 'capital' of this janapada (Yazdani 1960: 25). D. C. Sircar follows Yazdani in reiterating the same contention (Sircar 1960: 189).

It is thus evident that many instances where Paithan is reported as being mentioned in Buddhist literature are inferential and not substantive, the only exception being the story of Bāvari and his students from the Sutta Nipāta. Amongst later Buddhist texts, the Mahämayuri, a lexicon of Yaksha cults and their locations, mentions Paithan as the abode of a Yaksha named Khandaka (Agrawal 1942: 24-25).

\section{Jaina sources}

The major source of information on Paithan from Jaina sources is J. C. Jain's Life in Ancient India as Described in the Jain Canon and Commentaries (Jain 1984: 400-401). The Jaina texts Bṛhatkalpabhāṣya (vv. 6244-6249) and Vasudeva Hindi $(354,8)$ describe Paithan as the chief city of Maharashtra. The Kalpasūtra mentions Paithan as a seat of learning (4, 90a) and the GacchācārṾrtti (208) states that great scholars like Bhadrabahu and Varahamihira were residents of Paithan. Many Jaina texts mention Paithan explicitly in connection with the Satavahanas. For example, according to the Kālakāchärya Kathānaka, a Satavahana king (Sālivāhana) was ruling at Patiṭhāna when the Jaina monk Kālakāchārya visited him (Morwanchikar 1985: 19). According to another story that features in a text named Niśithacūrṇi (v. 3153), king Sālivāhana pleaded with Kālakāchārya to move the dates of Pajjusana, a Jaina festival. A text named Pindadaniryukti (v. 494, 498) states that a Jaina monk named Pādalitta Sūri cured the headache of a 'Murunda' king of Paithan (Bollée 1994: 29). The Murundas were an ancient tribe of North India, and their association with Paithan is otherwise unknown.
Jaina texts are replete with references to the Satavahana-Kshaharata conflict. According to the BrhatkalpaBhāssya Pịtikā, king Sālivāhana of Paithan lay siege to the Kshaharata capital Bharukachha (Skt Bhrgukachchha, or modern Bharuch) every monsoon (Deo 1975: 3). A text named Tiloya-Pannati states that a king named 'Naravahana' (Nahapana) ruled at Bharukachha and provides a chronology up to his rule, making a mention about his war with the 'Sālivāhana' of Paithan (Rajgor 1991: 34). In the Âvaśyakaniryukti (v. 1304), the Jaina scholar Bhadrabahu narrates an interesting story involving 'Nahavana', the king of Bharukachha, whose enemy was 'Satavahana', the king of Patițthāna. Satavahana besieged Bharuch for 2 years but could not take it, because Navahana could endure the siege owing to the riches he had accumulated through trade passing through the port of Bharuch. Satavahana then retreated and employed stealth tactics: he sent one of his ministers, named Kharaga, to Nahavana pretending he was defecting. Kharaga sought asylum at Bharuch and won over Nahavana's confidence. He influenced Nahavana's religious beliefs and encouraged him to give his wealth away in piety. Nahavana followed his advice and gave large donations to various sects. When he was thus impoverished, Satavahana attacked and defeated him.

There are a further two stories involving 'the Satavahana king' and Paithan. The first is about the king and his associate Śūdraka, while the second narrates origins of the cult of a local goddess named 'Pịthajādevì', practiced by married women (Jinaprabhasūri 61-64). Both stories mention many topographical features of the town and incorporate certain elements of the 'Satavahana myth' (see below).

\section{Brahmanic sources}

In the Early Medieval period, Paithan emerged as a pre-eminent centre of Brahmanic religion and thus finds a mention in several Brahmanic texts. These include the early Purānas, such as the Matsya and BrahmaPurāna, and later Purānas, such as the Padma and LingaPurāna (Morwanchikar 1985: 1, 11). The epic Mahabharata mentions a Pratishțhana-pura but it has been identified with Jhusi near Allahabad, known in Jaina sources as Poyanapura (Dey 1899: 71; Deo 1975: 1). In the BrahmaPuranna, the story is told of the son of king Surasena of Pratisthana, who is a Naga or snake (BrahmaPurāna 111). This son marries the daughter of king Vijaya, named Bhogavati, who finally discov- 
ers the divine, snake nature of her husband. They both go to the Gautami River to bathe. Eventually, the Naga rules the country together with his wife Bhogavati. At the death of his father (Surasena), he and Bhogavati go back to Sivapura (heaven).

It is considered important to perform Brahmanic rites such as Śrāddha for the deceased at Tïrthas (literally 'fords' for the soul to cross over to Moksha, its escape from the cycle of rebirths) where such rites could be held under Brahmanic supervision. A number of these evolved along the riverfront at Paithan so that it became a centre of pilgrimage and a 'SthalaPurāna' or religious site-guide named Pratishțhāna-Mahātmya for Paithan is also known and is included within the BrahmaPurāṇa text (Morwanchikar 1985: 11, 58).

\section{Secular Prakrit literature}

Paithan is mentioned in the Brhatkath $\bar{a}$, a prominent Prakrit literary work attributed to a poet named Gunāđhya and dated to the early Satavahana period, c. 100 BC-AD 100. Guñāđhya was not only a resident of Paithan but also had a Naga-Brahmana ancestry, similar to what was mythically claimed for the Satavahanas. Indeed, the Brhatkathā makes a mention of the Satavahana king, resident at Paithan, and contains a famous story about his ignorance of the Sanskrit language. It was also the first to incorporate a myth about the origins of the Satavahanas into a literary form. From Gunāđhya's Brhatkath $\bar{a}$, the literary lore surrounding Paithan was transmitted to Kathā-Saritsāgara of Somadeva and Brhatkathā-Manjirī of Kshemendra, which are dated roughly to the mid-first millennium $\mathrm{AD}$, and treat the Bṛhatkathā as their antecedent (Penzer 1968: 60ff).

The Gāthā Saptaśati, or Sattasaë as it is called in Prakrit, is a prominent Prakrit anthology said to have been patronized by the Satavahana ruler Hāla (around the early 1st century $\mathrm{AD}$ ). It has references to the River Godavari and urban life that flourished on its banks (Ketkar 1963: 397, 422).

\section{Western texts}

There is a general belief that many classical scholars like Arrian, Strabo and Pliny mention Paithan in various capacities. A fresh look at these sources confirms, however, that no direct reference to Paithan features in them. Many of the so-called references are mere implications based on mentions of other facts that subsequently became associated with Paithan. Yusuf's statement that Pliny mentions Paithan as the 'glorious capital of the Andhras' may serve as a case to illustrate this (Yusuf 1939: 39). The fact remains that Pliny mentions only the 'Andarae' but not Paithan while describing the peoples of India, following Megasthenes' description of Indian tribes (Pliny VI, 22). The 'Andarae' are identified with the 'Andhras', which in turn is the term that sources like the Purānas employ to describe the Satavahanas. A general belief prevails that the Satavahana 'capital' was located at Paithan (discussed below). It is evident that Yusuf has conflated all these disparate aspects to attribute a mention of Paithan to Pliny.

Specific references to Paithan are found in two Greek texts: first the Geographike Uphegesis (or General Geography) of Ptolemy and, second, the Periplus Maris Erythraei, a seafaring manual attributed to an unnamed Hellenic Egyptian who seems to have regularly plied the maritime trade route between the Red Sea and the Indian coastline. Both sources are roughly contemporary: the Periplus is dated to around AD 60-70, while Ptolemy's geography was written only a few decades later, in the late 1st to early 2 nd centuries AD (Schoff 1974: 7-15).

Chapter 51 of the Periplus describes Paithan as follows:

Of the trading centres in the region of Dachinabades, two are the most outstanding: Paithana, twenty days' travels to the south from Barygaza; and from Paithana, about ten days to the east, another very large city, Tagara. From these there is brought to Barygaza, by conveyance in wagons over very great road-less stretches, from Paithana large quantities of onyx, and from Tagara large quantities of cloth of ordinary quality, all kinds of cotton garments, garments of Molochinon and certain other merchandise from the coastal parts that finds a market locally there.

(Casson 1989: 82-83).

Here, 'Dachinabades' is evidently Dakshinapatha, the traditional Sanskrit term for the 'Southern Country'. 'Barygaza' is the Greek version of 'Bharukachha', the Prakrit name of modern Bharuch, and 'Tagara' is identified with Ter, an important emporium located in the Deccan hinterland.

Ptolemy's Geography (McCrindle 1885: 152) describes 'Baethana' as the 'royal seat' of a ruler named 'Siro Polemaios' - conceivably, the Satavahana ruler Vasithiputa Siri Pulumavi. This reference has been widely interpreted to identify Paithan as a 'capital' of the Satavahanas. In the same section, Ptolemy also mentions 
two other cities as 'royal seats': 'Ozene' as the seat of 'Tiastenes' and 'Hippokoura' as that of 'Baleokouros'. These rulers are respectively identified as the western Kshatrapa ruler Chashtana and a local ruler named Vilivayakura. Ptolemy thus affords a valuable 'isochronism' linking these three rulers and indicating their contemporaneity. While 'Ozene' is certainly Ujjayini or modern Ujjain, the identity of 'Hippokoura' is uncertain. This name features once more in Ptolemy's geography as that of a port on the western coast near 'Semylla/Tiamulla', or modern Chaul (McCrindle 1885: 359). In this instance, it can be safely identified with Kuda, a harbour-town south of Chaul, known for a complex of rock-cut caves. But based on Ptolemy's description, it is plausible to identify the 'Hippokoura' where 'Baleokouros' reigned as located not on the coast, but in the hinterland. Possibly, it was a Greek name of Brahmapuri near Kolhapur, which was a prominent emporium on trade routes that traversed the Deccan plateau and where a large number of coins of the Kura dynasty, to which two rulers named 'Vilivayakura' belonged, have been found (Rapson 1908: lxxxvi-lxxxvii).

\section{Marathi sources}

The town of Paithan is closely associated with the flourishing of Marathi literature in the late Yadava period (c. 12th-13th centuries AD). The Yadava capital at Devagiri (Daulatabad of present) was not situated very far from Paithan and the fact that Paithan had evolved as a prominent centre of Brahmanic religion in the centuries prior to Yadava rule meant it attracted the attention of the Yadavas, who patronized Brahmanism in a major way. The chief Marathi source for information on Paithan in this period is, however, the literature associated with the heterodox Mahānubhāva sect, which was founded by a seer named Śri Chakradhara in the mid-13th century AD (Morwanchikar 1985: 11).

Chakradhara travelled widely across the Marathwada and Vidarbha regions to preach his doctrines and won many followers. During these travels, he also visited Paithan and lived there for a while. It was at Paithan that he took vows of renunciation and became a Sanyāsin (mendicant). Early Mahānubhāva literature, such as Leelā-Charitra, Chakradhara's spiritual biography, Sthānpothì or the gazetteer of Mahānubhāva pilgrimage and Smrtisthala, a compilation of Chakradhara's memoirs, mentions Paithan at various instances (Raeside 1976: 587, 594).
Another religious sect that contributed widely to Marathi literature of the Yadava and post-Yadava or Sultanate periods was the egalitarian Varkari sect, which surrounded the cult of Vitthala or Vithoba, regarded as a form of Vishnu. A progenitor of the sect and pioneer of Marathi literature, Dnyaneshwara, was a resident of Paithan in his early life, where his father held a tenurial office of the 'Kulkarni'. Though many of Dnyaneshwara's early activities took place in Paithan, he himself does not mention the town in his literary works. The association with Dnayneshwara, however, meant that Paithan was noted in subsequent Varkari literature, starting with Dnyaneshwara's posthumous biography by his associate Namdeva (Morwanchikar 1985: 78-80).

In the late 15th to early 16th centuries, a noted Marathi 'saint' Eknath resided at Paithan. Eknath was a Brahmin and a follower of the egalitarian Vitthala sect. He was also acquainted with heterodox doctrines such as Sufism. He contributed immensely to Medieval Marathi poetic literature on the theme of Bhakti. Some events of his 'saintly' life, that live in the popular memory of Maharashtrians, took place at Paithan. Noteworthy amongst these is his embracement of a low-caste child along the banks of Godavari and another where he took a long journey back to the river so he could water a thirsty donkey (Morwanchikar 1985: 82-86).

\section{Folklore}

The folklore surrounding the origins of the Satavahana dynasty is intricately linked with Paithan. According to a folk story, a Brahmin lady lived in Paithan. When she went to fetch water at a place called 'Nagađoha' along the River Godavari, the Naga (serpent) king Śésha impregnated her. The child born out of this encounter was named Sālivāhana. As a child, he would make terracotta horses and soldiers to play with. When Vikrama, the ruler of Avanti (Ujjain), attacked the city of Paithan, Sālivāhana brought his toy army to life by sprinkling the magical nectar Amrta on it (according to mythical belief, the Nagas guarded repositories of Amrta in the Netherworld and Sālivāhana had access to it owing to his Naga parentage). He defeated Vikrama with the help of this army and subsequently became the first king of the Sālivāhana (or Satavahana) dynasty (Morwanchikar 1985: 9-10).

Another Medieval myth connects Vikrama with Sālivāhana of Paithan in a different way. According 
to this story, astrologers at Vikrama's court predicted that Vikrama would be slain at the hands of a man born in the Southern Country or Dakshināpatha. They also pronounced the tell-tale 'signs' of the killer. Disturbed by the oracle, Vikrama commanded Vetāla, the king of Bhūta spirits, to recognize and find him so he could be killed. Vetāla came to Paithan in his search and discovered that the 'signs' matched a boy named Sālivāhana, who lived in the city quarters inhabited by potters and mud-workers. He was playing with a terracotta army of horses and elephants when Vetāla spotted him. Vetāla reported his discovery to Vikrama, whereupon Vikrama launched an attack on Paithan. But Sālivāhana brought his toy army to life by magic and with its help defeated and killed Vikrama, thus fulfilling the prophecy (Ketkar 1963: 80-101).

These myths contain a curious combination of legend and reality. They surely refer, in an indirect manner, to the rivalry between Satavahanas and the Kshatrapas of Ujjain, but pose Vikrama, the mythical hero of Avanti, as the Satavahana enemy. The second version described above assimilates another well-known 'Vikrama' myth that of his association with the spirit-king Vetāla - into the Satavahana thread. The reference to the toy army seems to reflect popular memory about artefacts such as terracotta horses, elephants and human figurines being regularly unearthed at Paithan. It is also plausible that the Naga-Brahmana root of the Satavahanas was a historical reality, Nagas being a well-known ancient clan who were, in the course of time, mythified as the 'dwellers of the Netherworld' (Fergusson 1868: 125).

A popular belief that Paithan is a 'city turned upside down' (Ultī Nagarī to quote the Marathi term) reflects the archaeological reality of encountering older anthropogenic remains such as bricks under the ground during later-day construction and agricultural activities (Yusuf 1938: 3). Similar beliefs also exist about other ancient cities like Ujjain and usually a local myth flourishes around the causes of the city being turned upside down.

\section{Material sources}

\section{Stone inscriptions}

The inscriptional sources on Paithan are rather limited. Asoka, the great Mauryan emperor, mentions a people named 'Petenikas' or 'Pitinikas'. This mention has been widely recognized as a reference to the people of Paithan (Bhandarkar 1925: 32-33), the appellation deriving from a 'Prakritised' version of Paithan's Sanskrit name 'Pratishthana'. Two other peoples, namely the 'Rathikas' and 'Bhojakas', find a mention alongside the 'Petenikas' in the same edict. As these are identified amongst the early ethnic inhabitants of the Deccan plateau, their mention alongside the Petenikas helps the latter to be located in the same geopolitical region and thus adds support to the identification of the 'Petenikas' as the residents of Paithan. This claim, however, has been debated, mainly based on different ways the word could be derived from Sanskrit/Prakrit (Bhandarkar 1925: 32-33).

Amongst the inscriptions from Buddhist sites such as the cave temples of the Deccan, Paithan finds mention as 'Patithana', a Prakrit version of its Sanskrit name. Three inscriptions of a votive nature, one in Kanheri cave no. 3 and the other two in the Pitalkhora Chaitya cave, refer to residents of Paithan. The Kanheri inscription mentions the establishment of a monastery at Paithan (Lueders 1909-1910: 102, no. 988). The first of the Pitalkhora inscriptions makes note of a donation of a pillar by an unnamed 'Son of Saghaka', a resident of Paithan, while the second mentions the gift of a pillar by Mitadeva, from a perfumer (Gandhika) family of Paithan (Lueders 1909-1910: 137, nos. 1187-1188).

Although Paithan is widely regarded as a capital of the Satavahana dynasty (see below), it is not mentioned in any capacity in any Satavahana inscriptions. The names of ancient geopolitical regions Aśmaka and Mūlaka feature in the eulogy of Gotamiputa Siri Satakani inscribed in Nasik cave no. 3 by his son and successor Vasithiputa Siri Pulumavi (Lueders 1909-1910: 122, no. 1123). But we have already seen the fallacies involved in associating Paithan with such ancient regions.

\section{Copper-plates}

An administrative division or Āhāra named Supratishțha$\bar{a} h \bar{a} r a$ is mentioned in two Vakataka copper-plate charters, namely the Jamb copper-plate and the Wadegaon copper-plate of Pravarasena II (c. AD 400-440) (Mirashi 1963: 10-15, 53-56). The first copper-plate is dated to his 2nd regnalyear, and the second, to the 25th. The language of these plates is Sanskrit. V. V. Mirashi, while discussing the place names mentioned in the charters, tried to identify them using a 'structuralist linguistic' method, i.e. tracing the 'Sanskritisation' roots of modern place names. He therefore contended 
that the administrative division should be identified with the area surrounding the village Pothra in Hinganghat Taluka of Nagpur District. H. S. Thosar challenged this attribution and tried to show, following the same methodology as Mirashi, that the places mentioned in the plates can be located in the Marathwada region, and thus, the region around Paithan should be identified as Supratishțha-āhāra (for details of Thosar's arguments against Mirashi, see Morwanchikar 1985: 29-30). To further substantiate his claims, Thosar drew on secondary evidence from the Kathā-Saritsāgara (see above in the section on literary evidence), which refers to Paithan as Supratishtha Nagari. Thosar's contention that places mentioned in the copper-plates do exist in the Marathwada region is worthy of consideration. The fact remains, however, that Supratishțha-āhāra and Supratishțhita Nagari are two essentially different words, and even if one is linked to Paithan, to what extent the other can be linked in the same way is open to inquiry. Thosar's identification of Supratishțha-āhāra is therefore not conclusive.

Two copper-plate charters of the Rashtrakutas are associated with Paithan. The first, given by king Govind III (c. AD 793-814) in AD 794 and known as the 'Paithan copper-plates', records the donation of a village to a group of Brahmins (Kielhorn 1894-1895: 103-110). This village, named 'Limbārāmikā' in the plates, was part of an administrative division named Pratishțhana Bhukti, conceivably comprising the area around Paithan. Limbārāmikā is noted to have been a part of a group of 12 villages, known as 'Sārākachchha'. The second copper-plate charter given under the Rashtrakutas dates to the reign of king IndraIII(c. AD 914-929)and is known as the 'Jambgaon copper-plates' (Mirashi 1966: 223-238). It records the gift of a village named 'Khaërondhi', in celebration of the anniversary of Indra's coronation in AD 915. Khaërondhi is identified with Khirai, located a short distance to the north-west of Paithan. This copper-plate charter refers to Paithan by its Apabhramsa/ Prakrit name variant 'Paëțhāṇa'.

\section{The Satavahanas and Paithan}

As shown above, Paithan is recognized widely as the capital of the Satavahanas, mainly on the basis of textual sources. Most convincing amongst these is Ptolemy, who mentions 'Baithana' as the 'royal seat' of a king named 'Siro Polemaios' (Majumdar 1960: 376). It is to be noted that Ptolemy does not explicitly mention the town as the 'capital' of these kings; the term he uses is translated by McCrindle as 'royal seat', which may not necessarily mean a 'capital' in its true sense. Indeed, the modern connotations of the word 'capital' were unknown to classical writers such as Ptolemy.

What prompted Paithan's identification as a Satavahana 'capital' are the secondary corroborations to Ptolemy's reference which come from Indian sources. Chief amongst these are some of the Jaina sources described above but some substantiation is also to be found in the myths surrounding the origins of the Satavahana dynasty. The Prakrit secular literature described above also makes similar connections. It is worth noting, however, that both these sources hardly make a distinction between 'Satavahana' (and 'Salivahana' to use the term widely employed in the texts) as a dynasty and a person. As evident in these texts, 'Satavahana' as a dynastic name is non-existent; to them, it means only a personal name. This is rather ambiguous and undermines the reliability of such sources in drawing firm historical conclusions. Furthermore, it is also true that even these secondary sources do not explicitly mention Paithan as the 'capital'.

Inscriptional evidence from the Satavahana period is silent about Paithan and its association with the dynasty. The name of the town does not feature in any of the known Satavahana inscriptions, let alone there being a direct reference to the seat of government being there. The ancient regions Aśmaka and Mūlaka feature amongst those mentioned in the eulogy of Gotamiputa Siri Satakani inscribed in Nasik cave no. 3 and could, only indirectly and inferentially, be taken as a reference to Paithan. But we have already seen the fallacy of associating Paithan with these regions, owing to a general lack of evidence.

Archaeologically, there exists enough evidence to indicate that Paithan flourished under the Satavahana rule, but it does not offer any indications of the town being a capital. Recently, a sealing of a 'Royal Minister', or Rājāmātya, named Mahasenadata has been reported from Paithan (Godbole 2002-2003: pls II-III). Of the four sealings published by Godbole, two are fakes, whilst the other two are genuine but have been misread. Correct readings are 'Sivadatasa' ('of Sivadata', the name of an individual) and 'Rajamachasa Mahasenadatasa' (of the 'Royal Minister' Mahasenadata).

They can be dated on palaeographical grounds to the mid- or late-Satavahana period (c. 2nd-3rd centuries $\mathrm{AD}$ ) and could be taken as evidence of individuals with governmental responsibilities having resided at 
Paithan during the Satavahana period. This, however, still does not offer a full substantiation of the 'capital' being situated at Paithan. In this respect, it is worth noting that a Rājāmantya named Hala is mentioned in an inscription at Kuda (Lueders 1909-1910: 112, no. 1057), and other Amātyas, such as Sivakhadila and Vinhupalita, are known from Nasik inscriptions (Lueders 1909-10: 123-124, no. 1125). These do not necessarily indicate that both places were 'capitals'.

Notwithstanding this, the identification of Paithan as the Satavahana capital is often accepted without question. The reading and interpretations of certain epigraphic sources in conjunction with textual references (predominantly Ptolemy) have contributed to it, and in general to the debate.

R. G. Bhandarkar drew the inference that Dhanyakataka (present-day Dharanikota in the lowerGodavari or 'Amaravati' region of Andhra Pradesh) was a Satavahana 'capital' on the basis of a mention of a word which he read as Dhanakațakasāminehi in an inscription of Gotamiputa Siri Satakani at Nasik. R. G. Bhandarkar took the word as an adjective for the king's name and translated it 'by the Lord of Dhanyakataka', thereby inferring that the capital of Siri Satakani was situated at Dhanyakataka (Bhandarkar 1895: 41). But Senart, who edited and published this inscription in the late 19th century, read the word as Benakataka and not Dhanakataka (Senart 1905-1906: 7). V. V. Mirashi subsequently proved that the word was indeed Benakataka and corrected Bhandarkar's reading to Benākațakasamanehi, referring not to 'the Lord of Dhanyakataka' but to the monks (Samana, Skt. Sramana) from the region of Benakataka, or the valley of River Bena in Vidarbha (Mirashi 1979: [9]).
While successive researchers accepted this correction, Bhandarkar's assertion that Dhanyakataka was a Satavahana 'capital' has survived in the literature. Added to this was the need to accommodate Ptolemy's mention of Paithan. A curious assertion of historical detail followed this need - that of the Satavahana Empire having two capitals, one at Dhanyakataka and the other at Paithan (Yazdani 1960: 132). But it is evident that this has been inferred from erroneous data, namely the wrong reading of a word by Bhandarkar, and we have no further evidence that either city was Satavahana 'capital'.

To conclude, Paithan may have been a Satavahana city par excellence, and its early flourishing might be attributed to the Satavahana period. By the time of Ptolemy, it certainly seems to have become an emporium and was evidently a 'royal seat' of the Satavahana king Siri Pulumavi. The folklore and myths that surround the city may even have roots in the city's Satavahana past. It is important to emphasize, however, that there is no clear and unequivocal evidence that Paithan was the capital of the Satavahanas at any time. 